\title{
Association Between a Polymorphism at the Stearoyl CoA Desaturase Locus and Milk Production Traits in Italian Holsteins
}

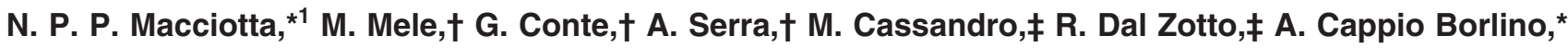 \\ G. Pagnacco,§ and P. Secchiari† \\ *Dipartimento di Scienze Zootecniche, Università di Sassari, Via de Nicola 9, 07100, Sassari, Italy \\ †Dipartimento di Agronomia e Gestione dell'Agroecosistema, Università di Pisa, Via del Borghetto 80, 56124 Pisa, Italy \\ łDipartimento di Scienze Animali, Università di Padova, Viale dell'Università 1635020 Legnaro, Padova, Italy \\ §Dipartimento di Scienze e Tecnologie Veterinarie per la Sicurezza Alimentare, Università di Milano, Via Celoria 10, 20133 Milano, Italy
}

\section{ABSTRACT}

Associations between stearoyl-CoA desaturase $(S C D)$ gene polymorphisms and milk production traits (milk, fat, and protein yields, fat and protein contents, somatic cell score) were investigated on a sample of 701 lactations of 313 Italian Holsteins. Test-day records $(5,097)$ were analyzed with a mixed linear model that included the fixed effects of herd, date of test, parity, genotype at the $S C D$ locus, and lactation interval nested within $S C D$ genotype, and the random effect of cow. An effect of the $S C D$ genotype on milk and protein yields was detected, with VV cows producing more milk (about $2 \mathrm{~kg} / \mathrm{d}$ ) and protein (about $0.07 \mathrm{~kg} /$ d) compared with AA cows. The contribution of the $S C D$ locus to the phenotypic variance of the 2 traits was about 0.015 . These results suggest a possible use of the $S C D$ locus in gene-assisted selection programs for the improvement of milk production traits in dairy cattle, although large-scale studies in different breeds are required.

Key words: dairy cattle, stearoyl-CoA locus, polymorphism, milk production trait

\section{INTRODUCTION}

Advancements in the identification of loci and chromosomal regions affecting traits of economic interest open appealing perspectives for the improvement of milk production traits in dairy cattle. Gene-assisted selection, that is, the use of functional mutations directly responsible of differences in phenotypes, is at present the most efficient option of marker-assisted selection (Dekkers, 2004). Loci with known effects on physiology of milk production have been proposed as candidate genes and relationships between their poly-

Received December 13, 2007.

Accepted April 21, 2008.

${ }^{1}$ Corresponding author: macciott@uniss.it morphisms and several dairy traits have been tested (Hayes and Goddard, 2001; Grisart et al., 2002; Khatib et al., 2007, 2008).

The stearoyl-CoA desaturase (SCD) locus has been suggested as a candidate gene affecting milk fatty acid (FA) profile (Gautier et al., 2006), a fundamental aspect of milk nutritional quality (Bauman et al., 2006; Soyeurt et al., 2006). The $S C D$ gene encodes a key enzyme of lipid metabolism able to introduce a double bond at the $\Delta^{9}$ position in a large spectrum of FA (Ntambi, 1999; Ntambi and Miyazaki, 2004). The SCD locus has been mapped on Bos taurus autosome (BTA)26 (Campbell et al., 2001). Three single nucleotide polymorphisms (SNP) in complete linkage disequilibrium resulting in 2 haplotypes have been detected in exon 5 (Taniguchi et al., 2004). The third SNP causes the substitution of valine (allele V) with alanine (allele A) on the 293rd residue. Because valine is highly conserved across mammals, it is considered the ancestral amino acid in that position (Taniguchi et al., 2004). The $S C D$ polymorphism has been found in Holstein-Friesian, Jersey, Brown Swiss, and Japanese Black cattle breeds (Taniguchi et al., 2004). Recently, an SNP polymorphism at the $3^{\prime}$ untranslated region (UTR) of the $S C D$ gene has been detected (Kgwatala et al., 2007).

Significant relationships between the polymorphisms in exon 5 of the $S C D$ locus and the FA profile of carcass fat (Taniguchi et al., 2004) and, more recently, of milk fat (Mele et al., 2007; Moioli et al., 2007) have been reported for cattle. In particular, an effect of the $S C D$ genotype on monounsaturated FA content and in the desaturase activity of the SCD enzyme has been detected in Italian Holsteins (Mele et al., 2007).

The aforementioned results suggest a possible use of the $S C D$ locus in gene-assisted selection programs for the genetic improvement of milk fat quality in dairy cattle. Moreover, it is reasonable to hypothesize that a gene involved in energetic pathways may affect other productive traits as milk, fat, and protein yields that 
Table 1. Number of records (n), raw test-day means and standard deviations for milk, fat, and protein yields (kg/d), fat and protein contents, and SCS for cows of different parities

\begin{tabular}{|c|c|c|c|c|c|c|c|c|c|}
\hline \multirow[b]{3}{*}{ Trait } & \multicolumn{9}{|c|}{ Parity } \\
\hline & \multicolumn{3}{|c|}{ First } & \multicolumn{3}{|c|}{ Second } & \multicolumn{3}{|c|}{ Third } \\
\hline & $\mathrm{n}$ & Mean & SD & $\mathrm{n}$ & Mean & SD & $\mathrm{n}$ & Mean & $\mathrm{SD}$ \\
\hline Milk yield (kg/d) & 2,564 & 29.94 & 6.21 & 1,760 & 33.29 & 9.91 & 1,512 & 36.59 & 10.44 \\
\hline Fat content (\%) & 2,462 & 3.634 & 0.786 & 1,695 & 3.705 & 0.877 & 1,468 & 3.614 & 0.789 \\
\hline Fat yield $(\mathrm{kg} / \mathrm{d})$ & 2,462 & 1.066 & 0.258 & 1,695 & 1.206 & 0.400 & 1,468 & 1.301 & 0.411 \\
\hline Protein content (\%) & 2,462 & 3.395 & 0.380 & 1,695 & 3.402 & 0.405 & 1,468 & 3.268 & 0.358 \\
\hline Protein yield $(\mathrm{kg} / \mathrm{d})$ & 2,462 & 1.002 & 0.178 & 1,695 & 1.110 & 0.277 & 1,468 & 1.176 & 0.291 \\
\hline SCS & 2,460 & 2.605 & 1.765 & 1,695 & 2.937 & 1.949 & 1,468 & 3.177 & 2.016 \\
\hline
\end{tabular}

represent the main breeding goals in current selection schemes. To verify this hypothesis, the relationships between the SNP polymorphism located in exon 5 of the $S C D$ locus and milk production traits in Italian Holstein cattle were investigated in this work.

\section{MATERIALS AND METHODS}

The data set contained 5,097 test-day (TD) records for milk, fat, and protein yields, fat and protein contents, and SCS measured on 701 lactations of 313 Italian Holstein cows. The original data set consisted of cows sampled from 21 half-sib families (14 \pm 2 daughters per bull) and distributed in 34 herds $(9 \pm 3$ cows per herd) located in the northeast of Italy. Data were recorded by the Italian Association of Animal Breeders within the official dairy recording plan in the period 1998-2004 (Table 1). Edits were based on the number of tests per lactation $(>2)$ and on parity $(<4)$.

The exon 5 region of the $S C D$ gene was amplified by PCR and the genotype at the $S C D$ locus for each cow was determined by an adapted single strand conformation polymorphism (SSCP) method (Ceriotti et al., 2004). Results were further checked by sequencing the DNA fragment that contained the polymorphism (Mele et al., 2007). Distributions of TD records, lactations, and cows across different $S C D$ genotypes and parities are reported in Table 2. Genotypes were not in Hardy-Weinberg equilibrium (chi-square $P=0.0002$ ), probably because of the limited size of the sample.

Data were analyzed with the following single-trait mixed linear model:

$$
\begin{aligned}
& \mathrm{y}_{\mathrm{ijklmn}}=\mathrm{TD}_{\mathrm{i}}+\mathrm{H}_{\mathrm{j}}+\mathrm{PAR}_{\mathrm{k}}+\mathrm{SCD}_{\mathrm{l}} \\
& +\mathrm{DIM}_{\mathrm{m}}\left(\mathrm{SCD}_{\mathrm{l}}\right)+\mathrm{c}_{\mathrm{n}}\left(\mathrm{SCD}_{\mathrm{l}}\right)+\mathrm{e}_{\mathrm{ijk} \mathrm{m} n}
\end{aligned}
$$

where $\mathrm{y}=$ test for milk, fat, or protein yields, fat or protein percentage, somatic cell score; $\mathrm{TD}=$ fixed effect of the date of the test (797 levels); $\mathrm{H}=$ fixed effect of the herd (32 levels); PAR = fixed effect of the parity (3 levels, 1st, 2nd, 3rd); SCD = fixed effect of the $S C D$ genotype $(\mathrm{AA}, \mathrm{AV}, \mathrm{VV}) ; \mathrm{DIM}=$ fixed effect of the stage of lactation (10 levels of $30 \mathrm{~d}$ each); $\mathrm{c}=$ random effects of each individual cow (313 levels), nested within $S C D$ genotype; and e = random residual.

Pairwise comparisons among different levels of fixed effects included in model [1] were performed using a Bonferroni adjusted test. The fixed effect of the $S C D$ locus allows for the estimation of the gene effect on the considered trait averaged for the whole lactation. Statistical significance of the $S C D$ effect was tested against variance of cow nested within $S C D$ genotype according to repeated measures design theory (Littell et al., 1998). The average effect of gene substitution at the $S C D$ locus was calculated as regression of the estimated least squares means of the 3 genotypes on the number of $\mathrm{V}$ alleles, weighted for the observed genotypic frequencies. The DIM factor nested within $S C D$ was included in the model to estimate lactation curves of the different $S C D$ genotypes (Stanton et al., 1992).

Random effects of cow and residual were assumed to be distributed with mean zero and (co)variance matrices $\mathbf{I} \sigma_{c}^{2}$ and $\mathbf{I} \sigma_{e}^{2}$, respectively. They allow for the

Table 2. Absolute frequencies of lactations and cows across the stearoyl CoA desaturase locus (SCD) genotypes and tests across parities and $S C D$ genotypes

\begin{tabular}{lccccc}
\hline & & \multicolumn{3}{c}{ Tests by parity, $\mathrm{n}$} \\
\cline { 4 - 6 } gen & & & First & Second & Third \\
\hline AA & Lactations, $n$ & Cows, $n$ & 635 & 503 & 399 \\
AV & 18 & 81 & 1,535 & 1,072 & 996 \\
VV & 431 & 40 & 368 & 214 & 107 \\
\hline
\end{tabular}


Table 3. Least squares means of test day for milk (MY), fat (FY), and protein (PY) yields (kg/d), fat (FC) and protein (PC) contents, and SCS for cows of different parities and stearoyl CoA desaturase locus (SCD) genotype

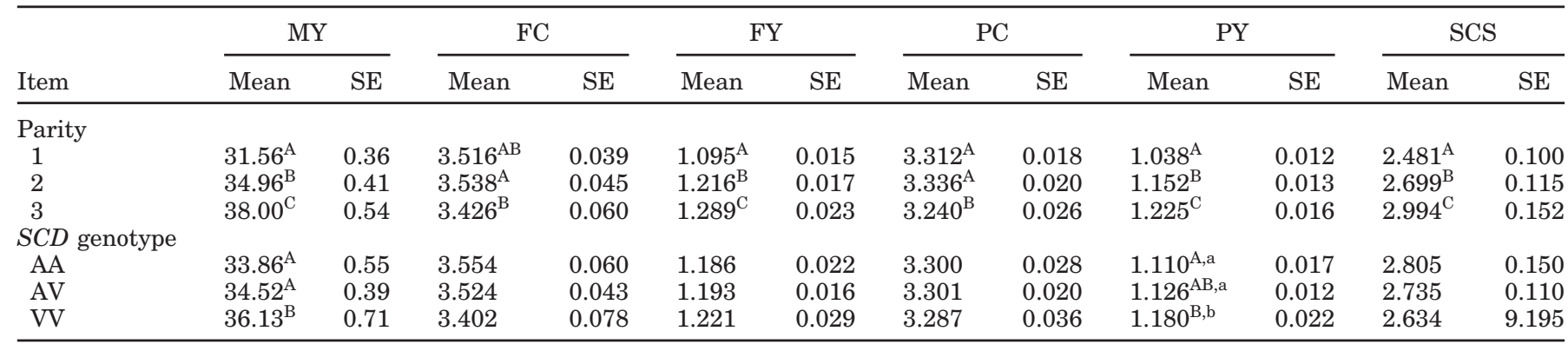

${ }^{\mathrm{a}, \mathrm{b}}$ Means within columns with different superscripts differ $(P<0.05)$.

${ }^{\mathrm{A}-\mathrm{C}}$ Means within columns with different superscripts differ $(P<0.01)$.

REML estimation of variance components associated to individual cow $\left(\sigma_{c}^{2}\right)$ and residual $\left(\sigma_{e}^{2}\right)$. The variance associated with the $S C D$ locus $\left(\sigma_{S C D}^{2}\right)$ was calculated according to Falconer and Mackay (1996):

$$
\sigma_{S C D}^{2}=2 p q[a+d(q-p)]^{2}
$$

where $\mathrm{p}$ and $\mathrm{q}$ are the frequencies of alleles $\mathrm{A}$ and $\mathrm{V}$, respectively; $a$ is half the difference between the 2 homozygotes; and $\mathrm{d}$ is the dominance deviation. The contribution of the stearoyl-CoA locus to the total phenotypic variance of the trait considered $\left(r_{S C D}^{2}\right)$ was then calculated as

$$
r_{S C D}^{2}=\frac{\sigma_{S C D}^{2}}{\sigma_{S C D}^{2}+\sigma_{c}^{2}+\sigma_{e}^{2}}
$$

Finally, to test for possible spurious associations between $S C D$ polymorphism and milk production traits due to polygenic effects, contrasts among different $S C D$ genotypes were estimated also by analyzing data with a model with the same structure of [1], but with the cow effect split into an additive genetic and a permanent environmental effect. The genetic (co)variance was structured by an additive relationship matrix that included cows with observations and their known ancestors up to 8 generations back in the pedigree, with a total number of 7,387 animals. To avoid model overparameterization, considering also the size of the data set, the permanent environmental (co)variance was modeled as $\mathbf{I} \sigma_{e p}^{2}$, where $\sigma_{e p}^{2}$ actually absorbs TD variation within and between lactations. (Co)variance components were estimated by a 6-trait REML animal model, by using the VCE software (Groeneveld, 1996).

\section{RESULTS AND DISCUSSION}

Herd, date of the test, and parity affected all the traits considered in the analysis ( $F$-test significance

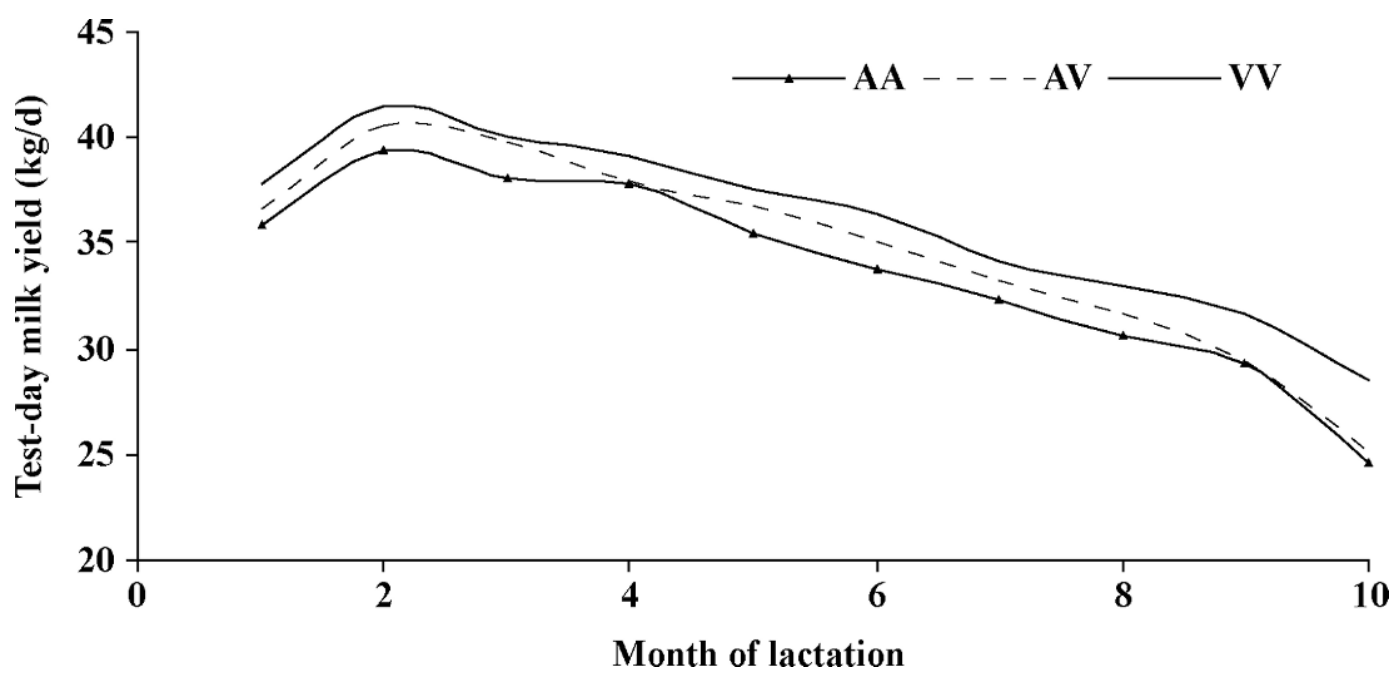

Figure 1. Estimated average lactation curves for milk yield of cows with different stearoyl-CoA desaturase genotypes. 
Table 4. Substitution effect of an alanine into a valine at the stearoyl CoA desaturase locus (SCD; mean $\pm \mathrm{SE}$ ) and contribution of the $S C D$ locus at the phenotypic variance for milk and protein yields

\begin{tabular}{lcccccc}
\hline Trait & $\alpha$ & $\sigma_{S C D}^{2}$ & $\sigma_{c}^{2}$ & $\sigma_{e}^{2}$ & $r_{c}^{2}$ & $r_{S C D}^{2}$ \\
\hline Milk yield (kg) & $1.040 \pm 0.27$ & 0.702 & 13.11 & 27.33 & 0.317 & 0.015 \\
Protein yield (kg) & $0.032 \pm 0.008$ & 0.0007 & 0.012 & 0.028 & 0.295 & 0.016 \\
\hline
\end{tabular}

level $P<0.001$ ), whereas a significant effect of the polymorphism at the stearoyl Co-A locus was found only for milk $(P=0.015)$ and protein $(P=0.011)$ yields.

Effects of parity and $S C D$ genotype are summarized in Table 3. As expected, least squares means of daily yields of milk, fat, and protein, and SCS tended to increase with parity, whereas fat and protein percentages showed an opposite trend.

Cows with genotype VV at the $S C D$ locus showed the greatest daily milk yield (Table 3 ), with more than $2 \mathrm{~kg} / \mathrm{d}$ compared with AA cows; heterozygous cows were in an intermediate position. Moreover, the difference between homozygous genotypes appeared to be constant across different lactation stages (Figure 1), whereas the behavior of the heterozygote was less regular. The allele substitution effect of alanine into valine was $1.04 \mathrm{~kg} / \mathrm{d}$, and the contribution of the $S C D$ polymorphism to the phenotypic variance was about $1.5 \%$ (Table 4).

There was no effect of the $S C D$ genotype on protein content, whereas the protein yield of VV cows was significantly greater than that of AA cows, with a difference of about $0.070 \mathrm{~kg} / \mathrm{d}$. In the case of protein yield, the difference between homozygous genotypes was constant throughout the lactation (Figure 2). The allele substitution effect was $0.032 \mathrm{~kg} / \mathrm{d}$, with a contribution to the phenotypic variance of protein yield of about
$1.6 \%$. No effect of $S C D$ genotype on fat content and SCS was observed (Table 3), even though VV cows showed lower values for both traits.

Differences among $S C D$ genotypes for milk and protein yields were confirmed by the analysis carried out with the relationship matrix (Table 5): VV cows were always the most productive for both traits, and differences among the 2 homozygous means were 2.15 and $0.055 \mathrm{~kg} / \mathrm{d}$ for milk and protein yield, respectively.

Estimates of heritability for all milk production traits considered (Table 6) are in agreement with previous reports on the Italian Holstein population (Muir et al., 2007) and, in general, with values reported in literature for dairy cattle (Ikonen et al., 2004; Ojala et al., 2005; Interbull, 2007).

Genetic correlations among yield and composition traits (above the diagonal of Table 6) are in agreement with the large literature available for these traits (Samoré et al., 2002; Miglior et al., 2007): in particular, high and positive genetic correlations between yield traits (ranging from about 0.56 to 0.87 ) and negative values for correlations between milk yield and fat and protein contents (about -0.42 ) can be observed. Finally, all correlations involving SCS were low $(<0.12)$.

Results of the present work showed an association between a polymorphism at exon 5 of the $S C D$ locus and milk and protein yields. Such an association ap-

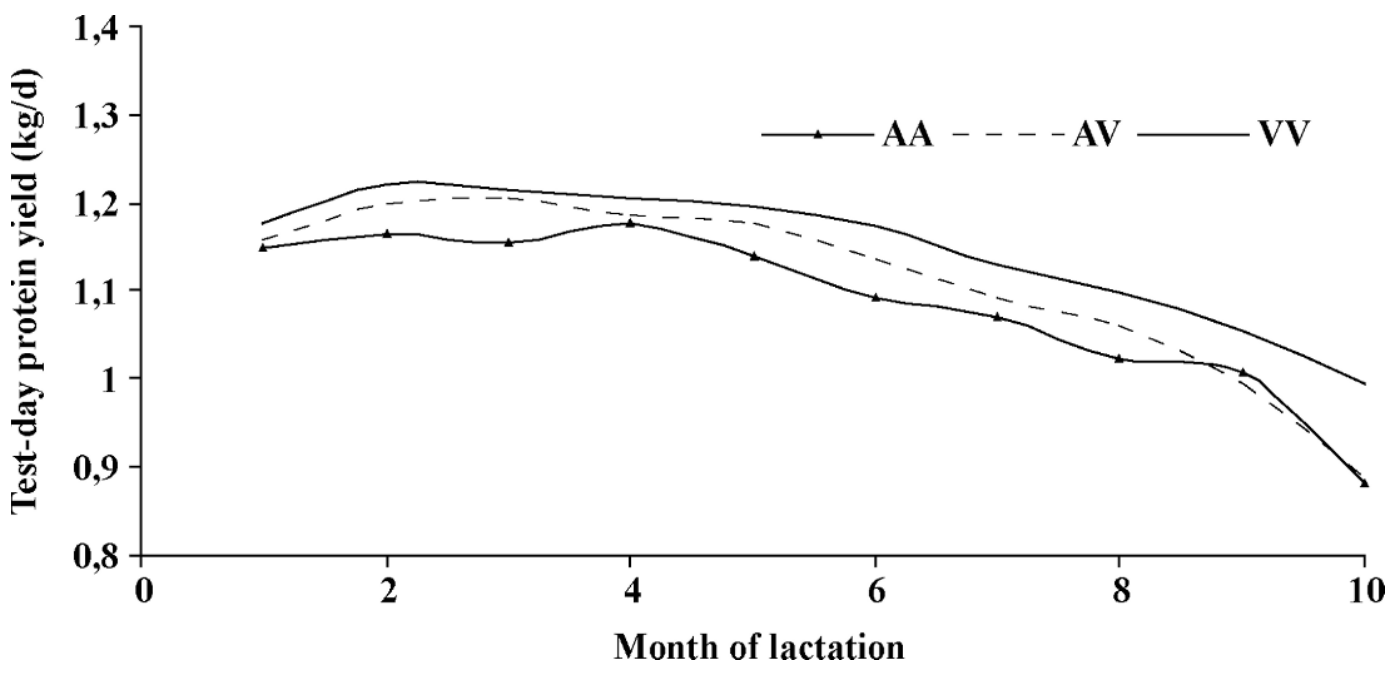

Figure 2. Estimated average lactation curves for protein yield of cows with different stearoyl-CoA desaturase genotypes. 
Table 5. Effects (Est) and standard errors (SE) of stearoyl CoA desaturase locus (SCD) genotypes for milk (MY), fat (FY), and protein (PY) yields ( $\mathrm{kg} / \mathrm{d})$, fat (FC) and protein (PC) contents, and SCS estimated with the model that included the additive genetic and permanent environmental effects ${ }^{1}$

\begin{tabular}{|c|c|c|c|c|c|c|c|c|c|c|c|c|}
\hline \multirow{2}{*}{$\begin{array}{l}S C D \\
\text { genotype }\end{array}$} & \multicolumn{2}{|c|}{ MY } & \multicolumn{2}{|c|}{$\mathrm{FC}$} & \multicolumn{2}{|c|}{$\mathrm{FY}$} & \multicolumn{2}{|c|}{$\mathrm{PC}$} & \multicolumn{2}{|c|}{ PY } & \multicolumn{2}{|c|}{ SCS } \\
\hline & Est & $\mathrm{SE}$ & Est & $\mathrm{SE}$ & Est & SE & Est & SE & Est & $\mathrm{SE}$ & Est & $\mathrm{SE}$ \\
\hline $\mathrm{AV}$ & 0.78 & 0.59 & -0.002 & 0.06 & 0.022 & 0.02 & 0.004 & 0.03 & 0.023 & 0.02 & -0.105 & 0.15 \\
\hline VV & 2.151 & 0.84 & -0.118 & 0.09 & 0.040 & 0.03 & -0.053 & 0.04 & 0.055 & 0.03 & -0.289 & 0.21 \\
\hline
\end{tabular}

${ }^{1}$ Values are expressed as a deviation from the reference genotype AA.

pears to be constant across different lactation stages and it is still confirmed when the polygenic background is accounted for. The magnitude of the gene effect, both in terms of substitution effect and contribution to the phenotypic variance of the traits, is comparable to results reported for the most well-known example of a gene found to affect milk production traits in cattle, the acyl-CoA diacylglycerol acyltransferase (DGAT1) gene (Grisart et al., 2002). Moreover, also for DGAT1, the occurrence of an effect of the same sign on both milk and protein yield has been reported (Grisart et al., 2002; Kühn et al., 2004).

Several studies have reported QTL located on BTA26 affecting milk, fat, and protein yields in Holsteins (Plante et al., 2001; Boichard et al., 2003; Viitala et al., 2003; Jiang et al., 2005; Druet et al., 2006). Moreover, some genes involved in lipid metabolism that are located on this chromosome including $S C D$, LPF (gastric lipase), or GPAM (glycerol-3-phosphate acyltransferase mitochondrial) have been suggested as possible candidate genes harboring the functional mutation detected by the QTL analysis. However, results of the work of Gautier and coworkers (2006) that used microsatellites close to these genes seem to exclude the possibility that the position of the $S C D$ locus matches the location of any of the QTL affecting milk production traits found on BTA26.

Finally, in previous research carried out on the same animals, VV cows showed lower contents of oleic, myristoleic, and monounsaturated fatty acids and a lower desaturase activity compared with AA cows (Mele et al., 2007). Actually, milk fat represents the major cost of milk synthesis (more than one half; Bauman et al., 1985), mainly due to energy requirements for FA neosynthesis and desaturation. It is therefore reasonable to hypothesize that in cows with greater desaturase activity, fewer nutrients are directed toward milk and protein yields. This relationship is partially confirmed by results obtained by Kay et al. (2005) that found that Holstein cows selected for milk fat yield produced more milk than cows from control line but with reduced $\Delta^{9}$-desaturase activity and lower monounsaturated FA content.

\section{CONCLUSIONS}

A polymorphism at the $S C D$ locus was found to be associated with daily milk and protein yields in a sample of Italian Holsteins. Moreover, the effect of the genotype was quite constant across lactation stages. The association between $S C D$ locus and milk production traits could be exploited in programs of gene-assisted selection for the genetic improvement of milk production traits, with particular regard to milk and protein yield. In any case, large-scale studies in the same and other dairy cattle populations are required to confirm the effect found in the present work and relationships with milk nutritional qualities.

\section{ACKNOWLEDGMENTS}

This research was funded by the Italian Ministry of University and research (grant PRIN 2005).

Table 6. Estimates of heritability (on the diagonal) and genetic correlations (above the diagonal) among milk (MY), fat (FY), and protein (PY) yields (kg/d), fat (FC) and protein (PC) contents, and SCS $^{1}$

\begin{tabular}{lcccrrr}
\hline Trait & MY & FC & FY & PC & PY & SCS \\
\hline MY, kg/d & 0.263 & -0.417 & 0.564 & -0.425 & 0.866 & 0.059 \\
FC, \% & & 0.283 & 0.511 & 0.614 & -0.151 & -0.124 \\
FY, kg/d & & 0.194 & 0.117 & 0.693 & -0.093 \\
PC, \% & & & 0.378 & 0.082 & -0.106 \\
PY, kg/d & & & & 0.250 & -0.005 \\
SCS, points & & & & & & 0.126 \\
\hline
\end{tabular}

\footnotetext{
${ }^{1}$ Standard errors of heritability estimates ranged from 0.017 to 0.027 ; standard errors of correlations estimates ranged from 0.026 to 0.109 .
} 


\section{REFERENCES}

Bauman, D. E., I. H. Mather, R. J. Wall, and A. L. Lock. 2006. Major advances associated with the biosynthesis of milk. J. Dairy Sci. 89:1235-1243.

Bauman, D. E., S. N. McCuthceon, W. D. Steinhour, P. J. Eppard, and S. J. Sechen. 1985. Sources of variation and prospects for improvement of productive efficiency in the dairy cow: A review. J. Anim. Sci. 60:583-592.

Boichard, D., C. Grohs, F. Bourgeois, F. Cerqueira, R. Faugeras, A. Neau, R. Rupp, Y. Amigues, M. Y. Boscher, and H. Leveziel. 2003. Detection of genes influencing economic traits in three French dairy cattle breeds. Genet. Sel. Evol. 35:77-101.

Campbell, E. M. G., D. S. Callagher, S. K. Davis, J. F. Taylor, and S. B. Smith. 2001. Mapping of the bovine stearoyl-coenzyme A desaturase (SCD) gene to BTA26. J. Anim. Sci. 79:1954-1955.

Ceriotti, G., S. Chessa, P. Bolla, E. Budelli, L. Bianchi, E. Duranti, and A. Caroli. 2004. Single nucleotide polymorphism in the ovine casein genes detected by polymerase chain reaction single strand conformation polymorphism. J. Dairy Sci. 87:2606-2613.

Dekkers, J. C. M. 2004. Commercial application of marker- and gene-assisted selection in livestock: Strategies and lessons. J. Anim. Sci. 82(E Suppl.):E313-E328.

Druet, T., S. Fritz, D. Boichard, and J. J. Colleau. 2006. Estimation of genetic parameters for quantitative trait loci for dairy traits in the French Holstein population. J. Dairy Sci. 89:4070-4076.

Falconer, D. S., and T. F. C. Mackay. 1996. Introduction to Quantitative Genetics. 4th ed. Longman Group Ltd., Harlow, UK.

Gautier, M., R. R. Barcelona, S. Fritz, C. Grohs, T. Druet, D. Boichard, A. Eggen, and T. H. E. Meuwissen. 2006. Fine mapping and physical characterization of two linked quantitative trait loci affecting milk fat yield on BTA26. Genetics 172:425-436.

Grisart, B., W. Coppieters, F. Farnir, L. Karim, C. Ford, P. Berzi, N. Cambisano, M. Mni, S. Reid, P. Simon, R. Spelman, M. Georges, and R. Snell. 2002. Positional candidate cloning of a QTL in dairy cattle: Identification of a missense mutation in the bovine DGAT1 gene with major effect on milk yield and composition. Genome Res. 12:222-231.

Groeneveld, E. 1996. User's Guide: REML-VCE—A multivariate multimodel restricted maximum likelihood (co)variance components estimation package. Version 4.0. Inst. Anim. Husbandry Anim. Behav., Fed. Agric. Res. Ctr., Neustadt, Germany.

Hayes, B., and M. E. Goddard. 2001. The distribution of the effects of genes affecting quantitative traits in livestock. Genet. Sel. Evol. 33:209-229.

Ikonen, T., A. Morri, A.-M. Tyrisevä, O. Ruottinen, and M. Ojala. 2004. Genetic and phenotypic correlations between milk coagulation properties, milk production traits, somatic cell count, casein content and pH of milk. J. Dairy Sci. 87:458-467.

Interbull. 2007. Description of national genetic evaluation systems for dairy cattle traits as applied in different Interbull member countries. http://www.interbull.slu.se/national_ges_info2/ framesida ges-htm.

Jiang, Z., S. De, M. D. Garcia, K. B. Griffin, X. L. Wu, Q. Xiao, J. J. Michal, B. S. Sharma, and G. B. Jansen. 2005. An independent confirmation of a quantitative trait locus for milk yield and composition traits on bovine chromosome 26. J. Anim. Breed. Genet. 122:281-284.

Kay, J. K., W. J. Weber, C. E. Moore, D. E. Bauman, L. B. Hansen, H. Chester-Jones, B. A. Crooker, and L. H. Baumgard. 2005. Effect of week of lactation and genetic selection for milk yield on milk fatty acid composition in Holstein cows. J. Dairy Sci. 88:3886-3893.

Kgwatala, P. M., E. M. Ibeagha-Awemu, J. F. Hayes, and X. Xhao. 2007. SNPs in the $3^{\prime}$ UTR of the Stearoyl-CoA desaturase gene in Canadian Holstein and Jerseys. J. Dairy Sci. 90(Suppl. 1):420. (Abstr.)
Khatib, H., R. L. Monson, V. Schutzkus, D. M. Kohl, G. J. M. Rosa, and J. J. Rutledge. 2008. Mutations in the STAT5A gene are associated with embryonic survival and milk composition in cattle. J. Dairy Sci. 91:784-793.

Khatib, H., I. Zaitoun, J. Wielbelhaus-Finger, Y. M. Chang, and G. J. M. Rosa. 2007. The association of bovine PPARGC1A and OPN genes with milk composition in to independent Holstein cattle populations. J. Dairy Sci. 90:2966-2970.

Kühn, C., G. Thaller, A. Winter, O. R. P. Bininda-Emonds, B. Kaupe, G. Erhardt, J. Bennewitz, M. Schwerin, and R. Fries. 2004. Evidence for multiple alleles at the DGAT1 locus better explains a quantitative trait locus with major effect on milk fat content in cattle. Genetics 167:1873-1881.

Littell, R. C., P. R. Henry, and C. B. Ammerman. 1998. Statistical analysis of repeated measures data using SAS procedures. J. Anim. Sci. 76:1216-1231.

Mele, M., G. Conte, B. Castiglioni, S. Chessa, N. P. P. Macciotta, A. Serra, A. Buccioni, G. Pagnacco, and P. Secchiari. 2007. StearoylCoA desaturase gene polymorphism and milk fatty acid composition in Italian Holsteins. J. Dairy Sci. 90:4458-4465.

Miglior, F., A. Sewalem, J. Jamrozik, J. Bohmanova, D. M. Lefebvre, and R. K. Moore. 2007. Genetic analysis of milk urea nitrogen and lactose and their relationships with other production traits in Canadian Holstein cattle. J. Dairy Sci. 90:2468-2479.

Moioli, B., G. Contarini, A. Avalli, G. Cavillo, L. Orr, G. De Matteis, G. Masoero, and F. Napoletano. 2007. Effect of stearoyl coenzyme A desaturase polymorphism on fatty acid composition of milk. J. Dairy Sci. 90:3553-3558.

Muir, B. L., G. Kistemaker, J. Jamrozik, and F. Canavesi. 2007. Genetic parameters for a multiple-trait multiple-lactation random regression test-day model in Italian Holsteins. J. Dairy Sci. 90:1564-1574.

Ntambi, J. M. 1999. Regulation of stearoyl-CoA desaturase by polyunsaturated fatty acids and cholesterol. J. Lipid Res. 40:1549-1558.

Ntambi, J. M., and M. Miyazaki. 2004. Regulation of stearoyl-CoA desaturases and role in metabolism. Prog. Lipid Res. 43:91-104.

Ojala, M., A.-M. Tyrisevä, and T. Ikonen. 2005. Genetic improvement of milk quality traits for cheese production. Pages 307 311 in Indicators of milk and beef quality. J. F. Hocquette and S. Gigli, ed. EAAP publication 112. Wageningen Academic Publishers, Wageningen, the Netherlands.

Plante, Y., J. P. Gibson, J. Nadesalingam, H. Mehrabani-Yeganeh, S. Lefebvre, G. Vandervoort, and G. B. Jansen. 2001. Detection of quantitative trait loci affecting milk production traits on 10 chromosomes in Holstein cattle. J. Dairy Sci. 84:1516-1524.

Samorè, A. B., P. Boettcher, J. Jamrozik, A. Bagnato, and A. F. Groen. 2002. Genetic parameters for production traits and somatic cell scores estimated with a multiple trait random regression model in Italian Holsteins. Proc. 7th World Congress on Genetics Applied to Livestock Production, Montpellier, France. Commun. no. 01-07.

Soyeurt, H., P. Dardenne, A. Gillon, C. Croquet, S. Vanderick, P. Mayeres, C. Bertozzi, and N. Gengler. 2006. Variation in fatty acid contents of milk and milk fat within and across breeds. J. Dairy Sci. 89:4858-4865.

Stanton, T. L., L. R. Jones, R. W. Everett, and S. D. Kachman. 1992 Estimating milk, fat, and protein lactation curves with a test day model. J. Dairy Sci. 75:1691-1700.

Taniguchi, M., T. Utsugi, K. Oyama, H. Mannen, M. Kobayashi, Y. Tanabe, A. Ogino, and S. Tsuji. 2004. Genotype of stearoylCoA desaturase is associated with fatty acids composition in Japanese Black cattle. Mamm. Genome 14:142-148.

Viitala, S. M., N. F. Schulman, D. J. de Konig, K. Eo, R. Kinos, A Virta, J. Virta, A. Maki-Tanila, and J. H. Vilkki. 2003. Quantitative trait loci affecting milk production traits in Finnish Ayrshire cattle. J. Dairy Sci. 86:1828-1836. 